\title{
UJI AKTIVITAS ANTIBAKTERI JAMUR ENDOFIT PADA DAUN DAN BATANG TUMBUHAN KUMIS KUCING (Orthosiphon aristatus) TERHADAP BAKTERI Escherichia coli DAN staphylococcus aureus
}

\author{
Excel Pangow ${ }^{1)}$, Jimmy Posangi ${ }^{2)}$, Widya Astuti Lolo ${ }^{1)}$, Robert A. Bara ${ }^{3)}$ \\ ${ }^{1)}$ Program Studi Farmasi FMIPA UNSRAT Manado, 95115 \\ ${ }^{2}$ Program PASCASARJANA UNSRAT Manado \\ ${ }^{3)}$ Program Studi Perikanan Ilmu Kelautan Unsrat Manado
}

\begin{abstract}
Endophytic fungi are fungi that live in plant tissues and do not harm the plants. Endophytic fungi can produce compounds that have the potential to be antibacterial. This study aims to examine the antibacterial activity of endophytic fungi isolated from the leaves and stems of the cat's whiskers plant (Orthosiphon aristatus) against Escherichia coli and Staphylococcus aureus bacteria. Cat's whiskers contain essential oils which are used as antibacterial against some pathogenic bacteria such as Staphylococcus aureus and Escherichia coli. The method used is experimentally in the laboratory to test the antibacterial activity of endophytic fungi isolates derived from cat's whiskers (Orthosiphon aristatus) on Escherichia coli and Staphylococcus aureus bacteria using the hole / well method. In the research results obtained four samples of endophytic fungi extract isolated from the leaves and stems of the cat's whiskers plant (Orthosiphon aristatus). The results of antibacterial research showed that endophytic mushroom extract isolated from cat's whiskers were more effective in inhibiting Escherichia coli bacteria compared to Staphylococcus aureus. In Escherichia coli bacteria the average value of inhibition is $5 \mathrm{~mm}$ whereas in Staphylococcus aureus bacteria the average value of inhibition is only $2 \mathrm{~mm}$. So it can be seen that the endophytic fungus from the leaves of cat's whiskers has a better antibacterial effect than the endophytic fungus from the stems of the cat's whiskets. Conclusion, etidophytic fungi isolated from leaves and stems of cat's whiskers (Orthosiphon aristatus) have an antibacterial effect on the growth of E. coli bacteria and are not effective against $S$. aureus bacteria.
\end{abstract}

Keywords: Cat's whiskers (Orthasiphan aristatus), antibacterial activity, Escherichia coli and Staphylococcus aureus.

\begin{abstract}
ABSTRAK
Jamur endofit ialah jamur yang hidup di dalam jaringan tumbuhan dan tidak membahayakan tumbuhan tersebut. Jamur endofit dapat menghasilkan senyawa yang berpotensi sebagai antibakteri. Penelitian ini bertujuan untuk menguji aktivitas antibakteri jamur endofit yang diisolasi dari daun dan batang tumbuhan kumis kucing (Orthosiphon aristatus) terhadap Bakteri Escherichia coli dan Staphylococcus aureus. Kumis kucing mengandung minyak atsiri yang digunakan sebagai antibakteri terhadap beberapa bakteri patogen seperti Staphylococcus aureus dan Escherichia coli. Metode yang dipakai yakni secara eksperimen di laboratorium untuk menguji adanya aktivitas antibakteri dari isolat jamur endofit yang diberasal dari tumbuhan kumis kucing (Orthosiphon aristatus) pada bakteri Escherichia coli dan Staphylococcus aureus dengan menggunakan metode lubang/sumuran. Pada hasil penelitan didapatkan empat sampel ekstrak jamur endofit yang diisolasi dari daun dan batang tumbuhan kumis kucing (Orthosiphon aristatus). Hasil penelitian antibakteri menunjukkan bahwa ekstrak jamur endofit yang diisolasi dari tumbuhan kumis kucing lebih efektif menghambat bakteri Escherichia coli dibandingkan dengan bakteri Staphylococcus aureus. Pada bakteri Escherichia coli nilai ratarata daya hambat yaitu $5 \mathrm{~mm}$ sedangkan pada bakteri Staphylococcus aureus nilai rata-rata daya hambat yaitu hanya $2 \mathrm{~mm}$. Sehingga dapat diketahui bahwa jamur endofit dari daun kumis kucing memiliki efek antibakteri yang lebih baik dibandingkan dengan jamur endofit dari batang kumis kucing. Kesimpulan, Jamur endofit yang diisolasi dari daun dan batang kumis kucing (Orthosiphon aristatus) memiliki efek antibakteri terhadap pertumbuhan bakteri E. coli dan tidak efektiv terhadap bakteri S. aureus.
\end{abstract}

Kata Kunci: Tumbuhan kumis kucing (Orthosiphon aristatus), aktivitas antibakteri, Escherichia coli dan Staphylococcu saureus. 


\section{PENDAHULUAN}

Indonesia memiliki ribuan tumbuhan yang tersebar di berbagai daerah. Keanekaragaman hayati tersebut dapat dimanfaatkan sebagai bahan baku obat. Pemanfaatan tumbuhan obat di indonesia secara tradisional memiliki efek samping yang lebih kecil dari obat yang dibuat secara sintesis. Penggunaan tumbuhan obat di masyarakat untuk mencegah penyakit, menjaga kesegaran tubuh maupun mengobati penyakit lainya (Rohana, 2011). Jenis tumbuhan yang digunakan sebagai tumbuhan obat, salah satunya adalah tumbuhan kumis kucing (Orthosiphon aristatus). Daun kumis kucing mengandung senyawa kimia yaitu alkaloid, flavonoid, tanin, polifenol, saponin (Alshaws, et, all., 2012). Banyak khasiat yang terkandung dalam tumbuhan kumis kucing ini. Daun kumis kucing basah maupun kering digunakan untuk menanggulangi berbagai penyakit (Sofiani, 2003).

$\begin{array}{rrr}\text { Bakteri } & \text { Escherichia coli dan } \\ \text { Staphylococcus } & \text { aureus } & \text { dapat }\end{array}$ menimbulkan penyakit sesuai dengan organ yang terinfeksi (Brook. 2001). Pada jaringan tumbuhan, terdapat jamur endofit yang menghasilkan senyawa yang berkhasiat seperti tumbuhan inangnya. Aktivitas senyawa yang dihasilkan jamur endofit lebih besar daripada aktivitas senyawa tumbuhan inangnya (Strobel, et, al., 2003).

Banyak peneliti yang berhasil mengisolasi jamur endofit dan senyawa metabolit sekunder dari berbagai jenis tanaman. Namun, penelitian yang mengisolasi jenis jamur endofit dari tanaman kumis kucing masih terbatas di Indonesia khususnya di kawasan Sulawesi Utara. Terbatasnya informasi tersebut, maka penulis melakukan penelitian mengenai isolasi dan aktivitas antibakteri jamur endofit pada tumbuhan kumis kucing terhadap bakteri Escherichia coli dan Staphylococcus aureus.

\section{METODOLOGI PENELITIAN Bentuk Penelitian}

Penelitian ini merupakan penelitian eksperimental dengan melihat aktivitas jamur endofit terhadap antibakteri.

\section{Waktu dan Tempat Penelitian}

Penelitian dilaksanakan pada bulan April hingga Agustus 2019 di Laboratorium Biologi Molekukuler dan Farmasetika Laut, Fakultas Perikanan Ilmu Kelautan, Universitas Sam Ratulangi, Manado. Kemudian di lanjutkan ke Laboratorium Farmasi Lanjutan, Program Studi Farmasi, Fakultas Matematika dan Ilmu Pengetahuan Alam, Universitas Sam Ratulangi, Manado.

\section{Alat dan Bahan \\ Alat}

Digunakan dalam penelitian ini yaitu gunting, sarung tangan, pinset, pemanas (kompor), erlenmeyer, gelas ukur, tabung reaksi, rak tabung reaksi, cawan petri, timbangan analitik, spatula, oven, pinset, batang pengaduk, pembakar spritus, pipet tetes, jarum ose, lemari pendingin, incubatorincucell(N-Biotek), laminary air flow (Clean Bench), autoklaf (autoklaf KT-30 ), mikropipet, jangka sorong, dan kamera ponsel.

\section{Bahan}

Digunakan pada penelitian ini yaitu daun dan batang tumbuhan kumis kucing (Orthosiphon aristatus), suspensi bakteri Staphylococcus aureus dan Escherichia coli, potato dextrose agar (PDA), Nutrient Agar (NA), alkohol 95\%, aquades, kloramfenikol kapsul, beras, etil asetat, ekstrak jamur endofit dari tumbuhan kumis kucing, kertas saring, kapas, larutan $\mathrm{NaCl}$, kertas label, aluminium foil dan tissue.

\section{ProsedurPenelitian Pengambilan Sampel}

$\begin{aligned} \text { Sampel yang digunakan pada } & \text { y } \\ \text { penelitian ini } & \text { sampel kumis kucing }\end{aligned}$


(Orthosiphon aristatus) diambil dari Jalan Teluk Bayur, Kota Manado

\section{Identifikasi Tanaman}

Identifikasi tanaman dilakukan di Laboratorium Biologi, Fakultas Matematika dan Ilmu Pengetahuan Alam,Universitas Sam Ratulangi, Manado.

\section{Sterilisasi Alat-alat}

Alat yang digunakan dalam penelitian ini disterilkan terlebih dahulu dengan oven dan autoklaf. Oven digunakan untuk mensterilisasi alat-alat untuk pembuatan media (cawan petri, ose, dan pinset). Autoklaf digunakan untuk mensterilisasi bahan-bahan pembuatan media dan alat gelas (erlenmeyer, tabung reaksi, dan media).

\section{Pembuatan Media PDA}

Media PDA yang akan dibuat sesuai dengan kebutuhan penelitian. Sebanyak 15 cawan petri yang akan digunakan maka media PDA ditimbang dengan berat 11,7 gr lalu ditambahkan natrium agar (NA) sebanyak 3,6 gr dan dilarutkan dalam $300 \mathrm{ml}$ aquades. PDA tadi dimasukan kedalam autoklaf untuk disterilisas dengan suhu $120^{\circ} \mathrm{C}$ selama 15 menit. Selanjutnya PDA tersebut dituangkan kedalam cawan petri yang sudah disterilisasi terlebih dahulu.

\section{Pembuatan Media PDA+ Antibiotik}

Proses pembuatan media $\mathrm{PDA}+\mathrm{AB}$ sama seperti pembuatan media PDA tetapi PDA ditambahkan dengan antibiotik kloramfenikol sebanyak $150 \mathrm{ml}$.

\section{Penanaman Sampel}

Sebelum ditanamkan kedalam media PDA+Antibiotik, dicelupkan terlebih dahulu alat (pinset, gunting) dan sampel yang akan digunakan dalam larutan alkohol 95\% selama 30 detik. Selanjutnya potongan sampel tersebut diangkat menggunakan pinset yg sudah direndam didalam larutan alkohol dan sudah dipijarkan di atas api selama 30 detik, potongan ini ditanam pada media Potato Dextrose Agar (PDA) + Antibiotik di dalam cawan petri, tiap cawan berisi empat potongan sampel.

\section{Pemurnian Jamur Endofit}

Pada hari ketiga setelah penanaman sampel akan diamati adanya miselia yang tumbuh dipermukaan media $\mathrm{PDA}+\mathrm{AB}$. Miselia yang sudah tumbuh diambil koloninya pada permukaan media dengan kawat ose dan dipindahkan ke media PDA yang lain untuk ditumbuhkan kembali. Pemurnian ini bertujuan untuk mendapatkan 1 jenis jamur endofit yang murni.

\section{Pembuatan Media Kulturnasi}

Pembuatan media ini menggunakan beras yang ditimbang sebanyak 40 gr dan aquades sebanyak $50 \mathrm{ml}$. Di masukkan kedalam Erlenmeyer untuk disterilisasikan kedalam autoklaf selama 10-15 menit pada suhu $120^{\circ} \mathrm{C}$. Setelah itu didinginkan untuk dilakukan penanaman miselia pada media nasi.

\section{Kultivasi dan Ekstraksi Jamur pada}

\section{Media Nasi}

Kultur jamur pada media nasi ini dilakukan selama 10 hari pada suhu ruang. Setelah pertumbuhan miselia jamur endofit mencapai bagian dasar dari labu erlenmeyer dilakukan ekstraksi. Proses ekstraksi dilakukan dengan cara maserasi menambahkan larutan etil asetat sebanyak $200 \mathrm{ml}$ sampai semua nasi terendam. Lalu diaduk dengan shaker selama 24 jam.

\section{Ekstraksi}

Ekstraksi dilakukan dengan cara maserasi, yaitu jamur yang telah dikultur direndam dengan cairan etil asetat dan diaduk diatas alat shaker selama 24 jam. Sampel yang sudah direndam, kemudian 
disaring menggunakan corong dan kertas saring sehingga menghasilkan filtrat 1 . Filtrat tersebut dimasukkan dalam labu evaporator. Evaporator dinyalakan dengan mengatur suhu selama $40^{\circ} \mathrm{C}$. Evaporasi dilakukan selama 20 menit dan didapatkan ekstrak.

\section{Pembuatan Larutan Suspensi Bakteri}

Bakteri yang telah dikultur pada agar miring diambil koloninya dengan kawat ose steril dan dimasukkan ke dalam larutan $\mathrm{NaCl} 5 \mathrm{ml}$. Suspensi bakteri dibuat dua buah. Pertama, Suspensi bakteri Staphylococcus aureus dan kedua, suspensi bakteri Escherechia coli,

\section{Pengujian Aktivitas Antibakteri}

Penanaman sampel dilakukan sebanyak 4 ekstrak sampel pada 4 tempat dalam cawan petri dan dengan jarak yang sama. Kemudian ditambahkan dengan kontrol positif dan kontrol negatife, sehingga sampel yang ada dalam cawan petri yaitu 6 (4 sampel adalah ekstrak jamur dan 2 sampel control). Metode yang digunakan yaitu metode lubang/sumuran dengan cara membuat lubang pada agar yang telah diinokulasi.

\section{Pengamatan Pengukuran Zona Hambat}

Pengamatan dilakukan 1x24 jam masa inkubasi. Diameter zona hambat diukur dalam satuan millimeter $(\mathrm{mm})$ menggunakan jangka sorong dengan cara mengukur jarak dari tepi sumur uji ke batas lingkaran zona hambat. Kemudian diameter zona hambat dikategori kekuatan daya anti bakterinya berdasarkan penggolongan oleh Davis dan Stout (1971).
Tabel 1. Klasifikasi zona Hambat menurut Davis dan Stout (1971)

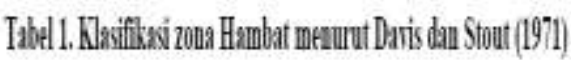

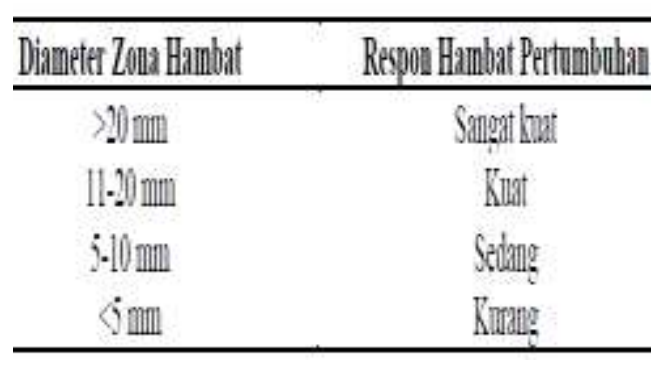

\section{HASIL DAN PEMBAHASAN}

\section{Isolat Jamur Endofit Kumis Kucing (Orthosiphon aristatus)}

Setelah mendapatkan jamur endofit yang tumbuh pada medium PDA setelah bebrapa hari, kemudian dimurnikan lagi dalam medium PDA baru dengan menginokulasi sedikit hifa jamur menggunakan kawat ose steril dari setiap koloni endofit yang berbeda. Potato Dextrose Agar (PDA) berguna sebagai karbohidrat yang merupakan sumber nutrisi bagi pertumbuhan jamur (Ariyono, 2014).

Setelah itu dilakukan kultur jamur endofit lalu di diamkan selama 3-7 hari pada suhu ruang. Hal ini bertujuan agar dapat memisahkan koloni endofit dengan morfologi yang berbeda sehingga mendapatkan isolat tersendiri (Tilesky, 2014).

Proses pengamatan pada fase pemisalahan ini selama 3-7 hari,akan tetapi jika masih ditemukan pertumbuhan koloni yang berbeda secara makroskopis, maka proses pemurnian akan di ulang kembali sampai diperoleh isolate yang murni. Setelah berhasil diisolasi dari tanaman menyebabkan inangnya dapat menghasilkan senyawa metabolit sekunder yang sama dengan yang dihasilkan oleh tanaman inangnya. Jamur endofit dikenal sebagai sumber metabolit sekunder berupa enzim atau senyawa bioaktif lainnya sehingga perlunya mengisolasi dan 
mengidentifikasi jamur endofit tersebut dari inangnya (Radji, 2005).

Hasil isolasi jamur endofit pada hari pertama sampai hari ke kelima dapat dilihat pada Gambar 1 dan 2.

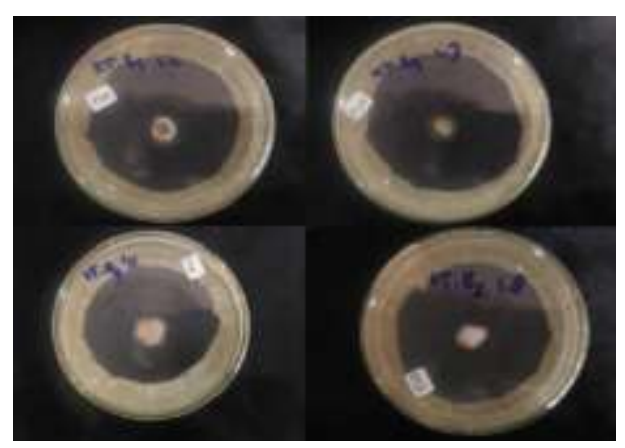

\section{Gambar 1. Hasil isolasi jamur endofit pada hari pertama}

(A)

(B)

(C)

(D)

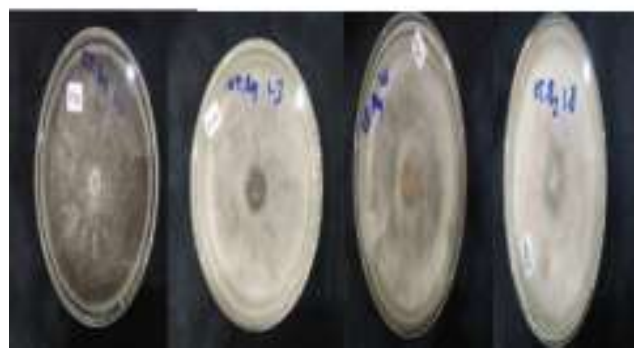

\section{Gambar 2. Hasil isolasi jamur endofit pada hari kelima}

Ket: (A). Jamur endofit pembiakan dari sampel daun Kumis Kucing (KK 1.2)

(B). Jamur endofit pembiakan dari sampel daun Kumis Kucing (KK.1.3)

(C) Jamur endofit pembiakan dari sampel daun Kumis Kucing (KK 1.4)

(D) Jamur endofit pembiakan dari sampel batang Kumis Kucing (KK 1.8)

\section{Kulturnasi dan Eksraksi Jamur Endofit}

Jamur endofit ini kemudian di kultur menggunakan media nasi yang secara static kurang lebih selama 10 hari lamanya pada suhu ruang, pertama kali dilakukan pada sampel dari daun kumis kucing dengan kode (KK.1.2), (KK.1.3) dan (KK.1.4) dan kemudian di lanjutkan sampel dari batang kumis kucing dengan kode (KK.1.8). Sesudah pertumbuhan miselia jamur endofit menutupi bagianbagian dari media nasi pada labu erlenmeyer kemudian dilanjutkan proses ekstraksi dengan cara maserasi. Maserasi adalah suatu proses perendaman sampel yang disertakan pelarut organik pada temperatur ruangan. Pada proses ini sangat menguntungkan dalam isolasi karena senyawa yang terdapat dalam sampel tumbuhan akan terjadi pemecahan dinding dan membran sel yang diakibatkan oleh perbedaan tekanan antara di dalam dan di luar sel, sehingga metabolit sekunder yang ada dalam sitoplasma akan terlarut dalam pelarut organik dan ekstraksi senyawa akan sempurna karena dapat diatur lama perendaman yang dilakukan. Pada pemilihan pelarut juga sangat berpengaruh untuk proses maserasi dikarenakan setiap pelalu berbeda-beda memberikan efektivitas pada kelarutan senyawa bahan alam tersebut. Setelah masuk dalam proses ekstraksi menggunakan cara maserasi yaitu dengan menambahkan larutan etil asetat sebanyak $200 \mathrm{ml}$ sampai semua sampelnya terendam kemudian lalu diaduk menggunakan alat shaker selama 1×24 jam. Maserasi digunakan karena ini merupakan metode ekstraksi sederhana yang sering digunakan (Mukhriani, 2014). Sehingga dapat menarik senyawa-senyawa aktif dari sampel dengan maksimal. Perendaaman sampel dalam maserasi dapat membuat dinding sel dari sampel pecah sekaligus membuat senyawasenyawa yang ada dalam sitoplasma akan tertarik oleh pelarut. Dinding sel pecah dikarenakan adanya perbedaan konsentrasi di dalam dan di luar sel. Konsentrasi diluar sel lebih tinggi dibandingkan konsentrasi di dalam sel yang rendah sehingga dinding sel pecah karena tidak bisa menahan tekanan dari perbedaan konsentrasi (Harborne, 1996). Waktu proses 
pengocokan diatas alat shaker selama 1x24 jam menghasilakn pelarut larut ke dalam sampel lalu akan masuk ke rongga-rongga sampel karena keadaan diam selama maserasi menyebabkan turunnya perpindahan bahan aktif. Untuk pelarut etil asetat ini merupakan senyawa organik dengan rumus empiris $\mathrm{CH} 3 \mathrm{COOC} 2 \mathrm{H} 5$. Senyawa ini berwujud cairan tak berwarna, memiliki aroma khas dan juga sebagai pelarut polar menengah yang volatil (mudah menguap), tidak beracun, dan tidak higroskopis. Setelah direndam dengan menggunakan etil asetat dilanjutkan disaring setelah itu di evaporasi menggunakan Rotary vacuum evaporator pada suhu $40^{\circ} \mathrm{C}$ (Yohanes, et, al.,2017). Evaporasi bertujuan untuk menguapkan ekstrak, penguapan dalam hal ini dimaksudkan agar air dan pelarut masih terisa dalam ekstrak akan menguap. Menggunakan suhu $40^{\circ} \mathrm{C}$ bertujuan untuk tetap menjaga senyawa bioaktif dalam filtrate kerena biasanya senyawa-senyawa bioaktif rentan terhadap suhu tinggi (Kowal, et, al.,2018). Kulturnasi jamur endofit kumis kucing dapat dilihat pada Gambar 3. dan hasil proses evaporasi dapat dilihat pada Gambar 4.

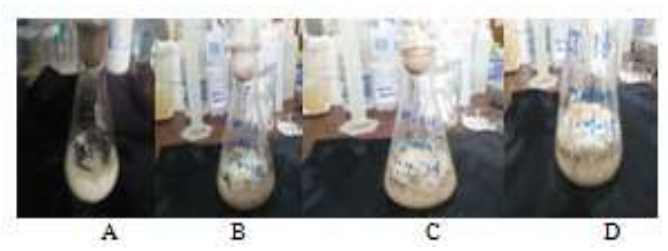

\section{Gambar 3. Proses kulturnasi dari jamur endofit tumbuhan kumis kucing}

Ket : A. Kulturnasi jamur endofit tumbuhan sampel KK 1.2

B. Kulturnasi jamur endofit tumbuhan sampel KK 1.3

C. Kulturnasi jamur endofit tumbuhan sampel KK 1.4

D. Kulturnasi jamur endofit tumbuhan sampel KK 1.8

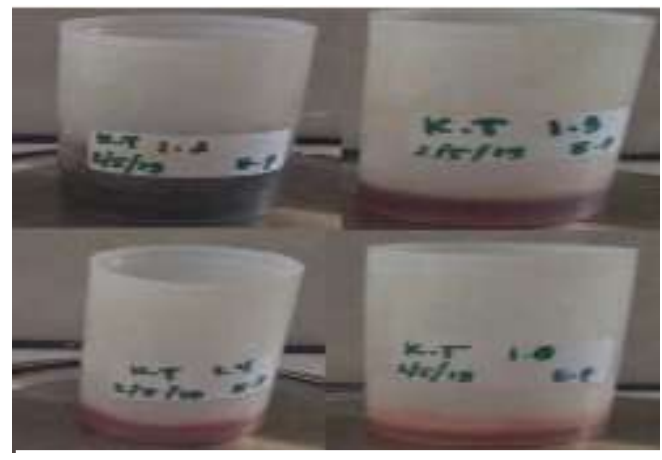

Gambar 4. Hasil dari evaporasi

\section{Pengujian Aktivitas Antibakteri}

Pengujian aktivitas antibakteri ini menggunakan bakteri Escherichia coli mewakili Gram negatif (Aquades) dan Staphylococcus aureus mewakili gram positif (Kloramfenikol). Pengujian dilakukan dengan mengukur zona hambat pada media agar setelah diinkubasi dalam alat inkubator selama 1x24 jam. Pertumbuhan bakteri setelah inkubasi terlihat menjauhi beberapa lubang sumuran, ini berarti terjadi pembentukan zona hambat di sekitar lubang sumuran yang telah ditotolkan sampel uji kumis kucing dan pada cakram antibiotik Kloramfenikol. Pada cakram kontrol negatif tidak terlihat adanya zona hambat.

Zona hambat yang terbentuk diukur diameternya dengan menggunakan jangka sorong dengan satuan milimeter $(\mathrm{mm})$. Pengukuran dilakukan dengan cara mengukur diameter dari ujung yang satu ke ujung yang lain. Pengujian aktivitas bakteri ini menggunakan metode difusi (sumuran) dimana masing-masing ektsrak diujikan pada masing-masing bakteri. Metode difusi digunakan karena prosedurya sederhana mudah dan praktis untuk dikerjakan dan dapat melihat sensitivitas berbagai jenis mikroba terhadap antimikroba (Kowal, et al.,2018). 
Iabet 2. Hasil pengekuman diameter zon bambat ekstrak kumb bucing

(OThosiphon oristatus) tertadap Escherichio coli.

\begin{tabular}{|c|c|c|c|c|c|c|}
\hline \multirow[t]{3}{*}{ Thangan } & \multicolumn{6}{|c|}{ Diameter zosa hambat (imin) terhadap Eschericinio coli } \\
\hline & Ekstonk & Ekstrak & Elstank & Elsude & Katiol & Koutrol \\
\hline & $\mathrm{KKI}: 2$ & KKL.3 & KKLA & $\mathrm{KK} 18$ & $(+)$ & (.) \\
\hline 1 & - & 2 am & , & . & $24 \mathrm{~mm}$ & \\
\hline II & - & f min & . & . & $x_{\mathrm{imm}}$ & \\
\hline III & . & $9 \mathrm{~mm}$ & - & . & $36=\mathrm{am}$ & - \\
\hline Iotal & . & $15 \mathrm{~mm}$ & & & & \\
\hline
\end{tabular}

Diameter zona hambat ekstrak dari kumis kucing (Orthosiphon aristatus) terhadap bakteri Escherichia coli yang paling besar dihasilkan oleh eksrak daun kumis kucing dengan kode KK 1,3 yaitu sebesar $9 \mathrm{~mm}$ dan termasuk kategori sedang menurut (Davis dan Stout 1971). Hasil pengukuran diameter zona hambat dapat dilihat pada Tabel 2 .

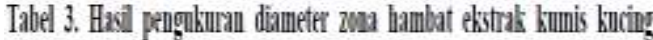

\begin{tabular}{|c|c|c|c|c|}
\hline \multirow[t]{3}{*}{ Chagin } & \multicolumn{4}{|c|}{ 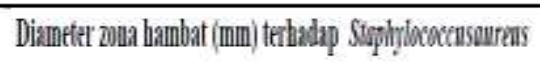 } \\
\hline & Elsond & Eksur & Elsod Elson & Kontal Komol \\
\hline & KKI:2 & $\mathrm{KK} 13$ & XKl.t XKI.8 & $(+) \quad(\cdot)$ \\
\hline I & . & $6 \mathrm{~mm}$ & . & $19.5 \mathrm{~mm}$ \\
\hline II & . & . & $2.5=$ & $19.5 \mathrm{~mm}$ \\
\hline $\begin{array}{l}\text { III } \\
\text { Iotal }\end{array}$ & . & $6 \mathrm{~mm}$ & $\begin{array}{l}1.5 \mathrm{winh} \\
4 \mathrm{mim}\end{array}$ & $16 \mathrm{~m} \cdot$ \\
\hline
\end{tabular}

Diameter zona hambat ekstrak dan kumis kucing (Orthosiphon aristatus) terhadap Staphylococcus aureus yang paling besar dihasilkan oleh daun kumis kucing dengan kode KK 1,3 yaitu sebesar $6 \mathrm{~mm}$ dengan kategori sedang. Hasil pengukuran diameter zona hambat dapat dilihat pada Tabel 3.
Berdasarkan hasil pengamatan yang dilakukan terhadap bakteri Escherichia coli danStaphylococcus masing-masing sebanyak tiga kali pengulangan memperlihatkan adanya zona hambat yang terbentuk disekitar lubang sumuran kecuali eksrak daun dengan kode KK 1,2 dan eksrak batang KK 1,8. Kedua eksrak ini tidak menunjukan adanya aktivitas antibakteri yang terbentuk, ini berarti kandungan senyawa antibakteri yang bersifat non polar pada kedua ektrak tersebut kurang, sedangkan pada ekstrak daun dengan kode KK 1,3 dan KK 1,8 memperlihatkan adanya aktivitas antibakteri terhadap Escherichia coli dan Staphylococcus aureus. Hal ini ditunjukan dengan terbentuknya zona hambat disekitar lubang sumuran sebesar $9 \mathrm{~mm}$ pada Escherichia coli tergolong sedang dan $6 \mathrm{~mm}$ pada Staphylococcus aureus juga tergolong sedang. Dari hasil ini menunjukan bahwa ekstrak daun dari tanaman kumis kucing (Orthosiphon aristatus) memiliki aktivitas sebagai antibakteri.

Hasil pengukuran diameter zona hambat digolongkan berdasarkan klasifikasi zona hambat menurut Davis and Stout (Tabel 1). Ekstrak daun dari tanaman kumis kucing (Orthosiphon aristatus) merupakan ekstrak yang lumayan efektif terhadap bakteri Escherichia coli dan Staphylococcus aureus karena memiliki daya hambat mikroba yang sedang. Gram positif hanya memiliki lapisan tunggal pada dinding selnya (Pelczar.1986). Sedangkan struktur dinding sel bakteri Gram negatif yang relatif kompleks akan menyebabkan senyawa antibakteri lebih sukar masuk ke dalam sel dan menemukan sasaran untuk bekerja (Siswandono.2000). Hal ini menerangkan bahwa bakteri gram positif lebih peka dibandingkan dengan bakteri gram negatif.

Kontrol positif memperlihatkan aktivitas antimikroba yang paling besar terhadap bakteri Escherichia coli dan Staphylococcus aureus. Kontrol positif yang digunakan yaitu Kloramfenikol. 
Kloramfenikol merupakan antibiotik yang memiliki spekrum luas terhadap bakteri (Katzung, 2004). Kontrol positif yang memiliki diameter daya hambat lebih besar yaitu $36 \mathrm{~mm}$ pada Escherichia coli dan Staphylococcus aureus $19.5 \mathrm{~mm}$.

Kontrol negatif tidak menunjukan terbentuknya zona hambat. Hal tersebut menandakan bahwa tidak ada pengaruh kontrol negatif terhadap bakteri yang diuji. Kontrol negatif yang digunakan yaitu aquades.

Aktivitas antibakteri yang terbentuk disekitar lubang sumuran ini disebabkan oleh aktivitas senyawa yang terkandung dalam ekstrak dan kumis kucing (Orthosiphon aristatus). Semakin besar zona hambat yang terbentuk maka semakin kuat senyawa yang terkandung dalam kumis kucing (Orthosiphon aristatus) untuk menghambat pertumbuhan bakteri.

\section{KESIMPULAN}

Aktivitas jamur endofit yang di isolasi dari daun dan batang tumbuhan kumis kucing (Orthosiphon aristatus) yang baik terdapat pada eksrak daun dengan kode KK 1,3. Daya hambat terhadap bakteri Escherichia coli adalah kategori sedang dan untuk bakteri Staphylococcus aureus adalah lemah.

\section{SARAN}

Diharapkan dapat dilakukan penelitian lebih lanjut mengenai efektifitas antibakteri ekstrak kumis kucing (Orthosiphon aristatus) untuk menunjang dalam terapi pengobatan.

\section{DAFTAR PUSTAKA}

Alshaws, M, A., Abdulla, M, A., Ismail, S., Amin, Z, A., Qader, S, W., Hadi, H, A., Harmal, N, S. 2012. Antimicrobial and Immuno modulatory Activities of Orthosiphon stamineus Benth. Journal of Molecular medicine. 17(2): 538-539.

Brooks. 2001. Mikrobiologi Kedokteran. Edisi ke-23. Jakarta.

Mukhriani. 2014. Mikrobiologi Kedokteran Edisi ke-20. Jakarta. EGC.

Strobel, A., Aly, A, H., Ebel, R, A., E, Müller, W, E, G., Mosaddak, M., Hakiki, A., Ebel, R., Proksch, P. 2003. Bioactive Secondary Metabolites from The Endophytic Fungus Chaetomium sp. Isolated from Salvia Officinalis Growing in Morocco. Journal Biotechnol Agron So Environ. 13(2): 229234.

Rohana ,O, S. 2011. Karakterisasi Simplisia, Skrining Fitokimia dan Uji Aktivitas Antibakteri Ekstrak Etanol Tumbuhan "Rosela" (Hibiscus sabdariffa L.) Terhadap Staphylococcus aureus dan Esherichia coli. Forum USU. Meta.

Radji, 2005. Diversitas Jamur Endofit pada Tanaman Padi (Oryza sativa L.) dan Potensinya Sebagai Pengendali Hama. Fakultas Pertanian. Universitas Mulawarman. Samarinda.

Sofiani, Y, S. 2003. Isolasi, Pemurnian, dan Uji Aktivitas Antibakteri Senyawa Sinensetin dari Ekstrak Daun Kumis Kucing (Orthosiphonis aristatus). Prodi Biokimia FMIPA. Institut Pertanian Bogor.

Tilesky Phoamda, 2014. Uji Efek Antibakteri Jamur Endofit Akar Bakau (Bruguiera gymnorhiza) Terhadap Bakteri Staphylococcus Aureus Dan Escherichia Coli. Jurnal e-Biomedik. 12 (2) No (1). Manado. 